(RESEARCH ARTICLE)

\title{
Oxcarbazepine effectiveness as add-on therapy in Bulgarian patients with drug- resistant epilepsy
}

\author{
Viteva Ekaterina Ivanova * and Zahariev Zahari Ivanov
}

Department of Neurology, Medical University - Plovdiv, Bulgaria, UMHAT St. George, Plovdiv, Bulgaria.

Publication history: Received on 09 September 2019; revised on 05 October 2019; accepted on 10 October 2019

Article DOI: https://doi.org/10.30574/wjarr.2019.3.3.0061

\begin{abstract}
The study purpose was to perform an open, prospective study on various aspects of oxcarbazepine (OCBZ) effectiveness in Bulgarian patients with drug-resistant epilepsy. The study was performed with the participation of patients with epilepsy who attended the Clinic of Neurology at the University Hospital in Plovdiv, Bulgaria. Patients completed diaries about seizure frequency, severity, and adverse events. There were regular documented visits at 3 or 6 months during the first year of treatment with OCBZ and at 6 months afterwards, with dynamic assessment of seizure frequency, severity, adverse events, and EEG recordings. OCBZ was applied as add-on treatment in 82 patients (44 males, mean age 40 years). There was a relatively mild and stable dynamic improvement of seizure severity, a satisfactory seizure frequency reduction in $25.6 \%$ of participants, a stable mean seizure frequency reduction (40$38.55 \%$ ) from the $6^{\text {th }}$ to the $24^{\text {th }}$ month of treatment and a stable responder rate $(39-48.6 \%)$ during the same period. There were adverse events (generalized rash, dizziness, nausea, vomiting, edemas of the extremities, memory problems) in $8.54 \%$ of patients. In conclusion, OCBZ treatment is associated with: a low and stable improvement of seizure severity, a good and stable improvement of seizure frequency, a possible worsening of seizure control, a good safety and tolerability.
\end{abstract}

Keywords: Oxcarbazepine; Epilepsy; Efficacy; Tolerability; Adverse events

\section{Introduction}

Oxcarbazepine (OCBZ) is an antiepileptic drug (AED) with the following mechanisms of action: inhibition of sodium and calcium channels, stabilization of the overexcited neuronal membranes, inhibition of the repetitive neuronal stimuli, limitation of synaptic impulses propagation. OCBZ has been confirmed as an appropriate drug for mono- and add-on therapy in children and adult patients with focal seizures with or without evolution to bilateral tonic-clonic seizures and with generalized tonic-clonic seizures. The frequent usage of OCBZ in the medical practice is a result of its broad spectrum effect on most types of epileptic seizures (with the exception of absences and myoclonic seizures), similar efficacy and better safety to that of the first-line conventional AEDs, making OCBZ their successful alternative. The possibility of rapid up-titration, the linear pharmacokinetics, the lack of necessity to monitor laboratory investigations (with the exception of hyponatremia), the low potential for drug interactions (with the exception of oral contraceptives and phenytoin) have been proven as important advantages.

Seizure frequency is the main efficacy outcome reported by investigators from randomized, double-blind, placebocontrolled, and open prospective studies on mono- and add-on treatment with OCBZ in patients with focal and generalized epilepsy. Dose-dependent variations from $26 \%$ to $50 \%$ of responders' percentage as well as reduction from $22 \%$ to $50 \%$ of the mean seizure frequency have been reported in patients with focal and generalized tonicclonic seizures [1-5]. The percentage of responders in open prospective studies varies up to 93\%, with seizure free patients up to 35\% [6]. Attention has not been focused on retention rate of OCBZ and the correlation of seizure frequency and severity dynamics with demographics and clinical findings. There are no reliable prospective studies on

\footnotetext{
${ }^{*}$ Corresponding author

E-mail address: eiviteva@abv.bg
} 
effectiveness of OCBZ in Bulgarian adult patients with drug-resistant epilepsy. Therefore, the conduction of an open, prospective study on various aspects of effectiveness of add-on therapy with OCBZ in Bulgarian patients with drugresistant epilepsy will provide additional useful data for the medical practice.

The purpose of the study is to perform an open, prospective study on various aspects of OCBZ effectiveness in Bulgarian patients with drug-resistant epilepsy.

\section{Patients and methods}

The study is open, prospective, with a possibility of using available detailed retrospective information about some participants. It was performed with the participation of patients with epilepsy who attended the Clinic of Neurology at the University Hospital in Plovdiv, Bulgaria for a regular examination in cases of unsatisfactory seizure control or for adverse events from treatment.

All study procedures were performed after the approval of the Local Ethics Commission at the Medical University, Plovdiv. Every patient was introduced to the study design and signed an informed consent form before participating in the study procedures. The following inclusion criteria were used: 1 . A signed informed consent form; 2 . Consent of the patient and relatives about giving the required information and medical records; 3 . Age $\geq 18$ years; 4 . Diagnosis of epilepsy; 5. Good compliance of patients to recommended treatment; 6. A stable dose of concomitant AEDs in the recent 3 months; 7. A period of prospective observation of at least 3 months; 8 . Completed diary about seizure frequency, severity, and adverse events; 10. Regular documented visits at 3 or 6 months during the first year of treatment and at 6 months or 1 year afterwards, with dynamic assessment of seizure frequency, severity, adverse events, and EEG recordings. The criteria for AEDs choice are in conformity with the approved by the National Drug Agency indications.

Data were collected by a trained neurologist specialized in epilepsy through an examination of the patients' medical documentation and a detailed interview on the disease onset, heredity, concomitant diseases, type and etiology of epilepsy, seizure type, frequency and severity, treatment with AEDs, efficacy of OCBZ, adverse events from treatment. Seizure frequency dynamics was based on patients' seizure diaries. Seizure severity was estimated on the basis of information about seizure duration, traumatism during seizures, duration of consciousness loss, severity of postictal manifestations. Adverse events from treatment were assessed as type, severity (mild, moderate, severe), and duration based on reports from patients and relatives, a standardized interview based on the validated by Kuzmanova et al. Bulgarian version of the Liverpool Adverse Events profile [7], a physical, and neurological status examination at every visit.

Data were processed using STATA (Stata Corp., College Station, TX, USA) and SPSS (Statistical Package for the Social Sciences) version 13.0 (SPSS Inc., Chicago, IL, USA). The results for quantitative variables were expressed as means \pm SE (standard error) and the results for qualitative variables as percentages. The principal outcomes were: clinical efficacy (effect on seizure frequency and severity, treatment duration and reasons for withdrawal, new seizure types, treatment changes), and tolerability (adverse events). The association of dynamics in seizure frequency and severity with demographics, and clinical findings was tested by means of $\chi 2$-test. The level of significance was set at $\mathrm{P}<0.05$.

\section{Results}

\subsection{Demographic and clinical characteristics of the study participants}

The total number of patients diagnosed with epilepsy who have attended the Clinic of Neurology for the period 20032016, was 1259 (in- and outpatients). OCBZ was applied in 82 patients of 18-64 years of age (mean age 40.46 \pm 0.39 ). The onset of epilepsy varied from 10 days to 57 years of age, mean age onset $19.66 \pm 0.42$ years. The mean epilepsy duration varied from 5 to 50 years, mean duration - $21.76 \pm 0.39$ years. The observation continued from 2 to 108 months, (23.93 \pm 0.5 months). The commonest dosage of LTG was $1200 \mathrm{mg} / \mathrm{d}$ and $1800 \mathrm{mg} / \mathrm{d}$, mean dosage $1242 \pm$ $2.12 \mathrm{mg} / \mathrm{d}$. The demographic and clinical characteristics of the study participants are presented in Table 1. 
Table 1 Demographic and clinical characteristics of patients on treatment with OCBZ

\begin{tabular}{|c|c|c|c|c|}
\hline \multicolumn{2}{|c|}{ Demographic/ clinical characteristic } & \multirow{2}{*}{$\begin{array}{l}\mathbf{N} \\
44\end{array}$} & \multirow{2}{*}{$\begin{array}{l}\mathbf{P}(\%) \\
53.7\end{array}$} & \multirow{2}{*}{$\begin{array}{l}\text { SE } \\
5.54\end{array}$} \\
\hline Gender & Males & & & \\
\hline & Females & 38 & 46.3 & 5.54 \\
\hline \multirow{4}{*}{$\begin{array}{l}\text { Age at the study } \\
\text { onset (years) }\end{array}$} & $\leq 25$ & 11 & 13.4 & 3.79 \\
\hline & $26-35$ & 16 & 19.6 & 4.41 \\
\hline & $36-45$ & 22 & 26.8 & 4.92 \\
\hline & $>45$ & 33 & 40.2 & 5.45 \\
\hline \multirow{2}{*}{$\begin{array}{l}\text { Age at epilepsy } \\
\text { onset }\end{array}$} & $\leq 18$ years & 49 & 59.8 & 5.45 \\
\hline & $>18$ years & 33 & 40.2 & 5.45 \\
\hline \multirow[t]{2}{*}{ Epilepsy duration } & $\leq 10$ years & 18 & 22.0 & 4.60 \\
\hline & $>10$ years & 64 & 78.0 & 4.60 \\
\hline \multirow{10}{*}{$\begin{array}{l}\text { Study duration } \\
\text { (months) }\end{array}$} & $<6$ & 3 & 3.6 & - \\
\hline & 6 & 15 & 18.3 & 4.30 \\
\hline & 12 & 20 & 24.4 & 4.77 \\
\hline & 24 & 24 & 29.3 & 5.06 \\
\hline & 30 & 1 & 1.2 & - \\
\hline & 36 & 9 & 11.0 & 3.48 \\
\hline & 48 & 1 & 1.2 & - \\
\hline & 60 & 3 & 3.7 & - \\
\hline & 72 & 5 & 6.1 & 2.66 \\
\hline & 108 & 1 & 1.2 & - \\
\hline \multirow[t]{4}{*}{ Seizure type } & Focal seizures with impaired awareness & 1 & 1.2 & - \\
\hline & Focal with evolution to bilateral tonic-clonic seizures & 37 & 45.1 & 5.53 \\
\hline & Generalized tonic-clonic seizures & 22 & 26.8 & 4.92 \\
\hline & Focal and generalized seizures & 22 & 26.8 & 4.92 \\
\hline \multirow[t]{2}{*}{ Type of epilepsy } & Focal & 52 & 63.4 & 5.35 \\
\hline & Generalized & 30 & 36.6 & 5.35 \\
\hline \multirow{3}{*}{$\begin{array}{l}\text { Etiology } \\
\text { epilepsy }\end{array}$} & Genetic & 8 & 9.8 & 3.30 \\
\hline & $\begin{array}{l}\text { Structural/ metabolic (traumatic, vascular, } \\
\text { inflammatory, tumor, hippocampal sclerosis, tuberous } \\
\text { sclerosis, hydrocephalus, encephalopathy, neurolupus) }\end{array}$ & 37 & 45.1 & 5.53 \\
\hline & Unknown & 37 & 45.1 & 5.53 \\
\hline \multirow{4}{*}{$\begin{array}{l}\text { Concomitant } \\
\text { diseases }\end{array}$} & No & 40 & 48.8 & 5.55 \\
\hline & Somatic & 33 & 40.2 & 5.45 \\
\hline & Psychiatric & 7 & 8.5 & 3.10 \\
\hline & Neurological & 2 & 2.4 & - \\
\hline \multirow{2}{*}{$\begin{array}{l}\text { Seizure clusters } \\
\text { and/or status } \\
\text { epilepticus in the } \\
\text { disease course }\end{array}$} & Yes & 40 & 48.8 & 5.50 \\
\hline & No & 42 & 50.2 & 5.50 \\
\hline \multirow{2}{*}{$\begin{array}{l}\text { Cognitive } \\
\text { functions }\end{array}$} & Normal & 69 & 84.1 & 4.06 \\
\hline & Mental retardation/ cognitive deficit & 13 & 15.9 & 4.06 \\
\hline \multirow{2}{*}{$\begin{array}{l}\text { Neurological } \\
\text { status }\end{array}$} & Normal & 63 & 76.8 & 4.69 \\
\hline & With focal neurological signs & 19 & 23.2 & 4.69 \\
\hline
\end{tabular}




\begin{tabular}{|c|c|c|c|c|}
\hline \multirow{4}{*}{$\begin{array}{l}\text { Recent seizure } \\
\text { frequency }\end{array}$} & 1-11 seizures/year & 5 & 6.1 & 2.66 \\
\hline & 1-3 seizures/month & 23 & 28.0 & 4.99 \\
\hline & 1-6 seizures/ week & 40 & 48.8 & 5.55 \\
\hline & Daily & 14 & 17.1 & 4.18 \\
\hline \multirow{2}{*}{$\begin{array}{l}\text { Recent } \\
\text { severity }\end{array}$} & Mild & 8 & 9.8 & 3.30 \\
\hline & Severe & 74 & 90.2 & 3.30 \\
\hline \multirow{2}{*}{$\begin{array}{l}\text { AED treatment at } \\
\text { study onset }\end{array}$} & Monotherapy & 53 & 64.6 & 5.31 \\
\hline & Polytherapy & 29 & 35.4 & 5.31 \\
\hline \multirow{7}{*}{$\begin{array}{l}\text { Initial } \\
\text { dosage }\end{array}$} & $600 \mathrm{mg} / \mathrm{d}$ & 7 & 8.5 & 3.10 \\
\hline & $750 \mathrm{mg} / \mathrm{d}$ & 1 & 1.2 & - \\
\hline & $900 \mathrm{mg} / \mathrm{d}$ & 11 & 13.4 & 3.79 \\
\hline & $1200 \mathrm{mg} / \mathrm{d}$ & 41 & 50.0 & 5.56 \\
\hline & $1500 \mathrm{mg} / \mathrm{d}$ & 5 & 6.1 & 2.66 \\
\hline & $1800 \mathrm{mg} / \mathrm{d}$ & 16 & 19.5 & 4.40 \\
\hline & $2100 \mathrm{mg} / \mathrm{d}$ & 1 & 1.2 & - \\
\hline \multirow[t]{18}{*}{ Concomitant AED } & Monotherapy OCBZ $1200-1500 \mathrm{mg} / \mathrm{d}$ & 8 & 9.8 & 3.30 \\
\hline & VPA $900-2000 \mathrm{mg} / \mathrm{d}$ & 40 & 48.8 & 5.55 \\
\hline & CZP 2-6 mg/d & 2 & 2.4 & - \\
\hline & TPM $300-400 \mathrm{mg} / \mathrm{d}$ & 3 & 3.7 & - \\
\hline & PHT $150 \mathrm{mg} / \mathrm{d}$ & 1 & 1.2 & - \\
\hline & LTG $250 \mathrm{mg} / \mathrm{d}$ & 1 & 1.2 & - \\
\hline & VPA $1500-1750 \mathrm{mg} / \mathrm{d}+\mathrm{LEV} 2000 \mathrm{mg} / \mathrm{d}$ & 2 & 2.4 & - \\
\hline & VPA $600-2000 \mathrm{mg} / \mathrm{d}+$ LTG $200-300 \mathrm{mg} / \mathrm{d}$ & 4 & 4.9 & - \\
\hline & VPA $1500-2000 \mathrm{mg} / \mathrm{d}+$ TPM $100-200 \mathrm{mg} / \mathrm{d}$ & 5 & 6.1 & 2.66 \\
\hline & VPA $1500-2500 \mathrm{mg} / \mathrm{d}+$ CZP $1.5-6 \mathrm{mg} / \mathrm{d}$ & 5 & 6.1 & 2.66 \\
\hline & VPA $1250-1750 \mathrm{mg} / \mathrm{d}+\mathrm{GBP} 1200-1600 \mathrm{mg} / \mathrm{d}$ & 4 & 4.9 & - \\
\hline & CZP $2 \mathrm{mg} / \mathrm{d}+\mathrm{LTG} 300 \mathrm{mg} / \mathrm{d}$ & 1 & 1.2 & - \\
\hline & PHT 200 mg/d + LTG 300 mg/d & 1 & 1.2 & - \\
\hline & TGB $40 \mathrm{mg} / \mathrm{d}+\mathrm{CZP} 2 \mathrm{mg} / \mathrm{d}$ & 1 & 1.2 & - \\
\hline & LEV $2000 \mathrm{mg} / \mathrm{d}+\mathrm{CZP} 6 \mathrm{mg} / \mathrm{d}$ & 1 & 1.2 & - \\
\hline & LTG $250 \mathrm{mg} / \mathrm{d}+\mathrm{PGB} 300 \mathrm{mg} / \mathrm{d}$ & 1 & 1.2 & - \\
\hline & VGB $1000 \mathrm{mg} / \mathrm{d}+\mathrm{LTG} 300 \mathrm{mg} / \mathrm{d}+\mathrm{LEV} 2000 \mathrm{mg} / \mathrm{d}$ & 1 & 1.2 & - \\
\hline & VPA $1500 \mathrm{mg} / \mathrm{d}+$ TPM $200 \mathrm{mg} / \mathrm{d}+\mathrm{CZP} 3 \mathrm{mg} / \mathrm{d}$ & 1 & 1.2 & - \\
\hline \multirow{7}{*}{$\begin{array}{l}\text { EEG at the study } \\
\text { onset }\end{array}$} & Normal & 37 & 45.1 & 5.53 \\
\hline & Focal activity & 26 & 31.7 & 5.17 \\
\hline & Generalized paroxysmal activity & 3 & 3.7 & - \\
\hline & Diffuse epileptiform activity & 3 & 3.7 & - \\
\hline & Diffuse slow-wave activity & 5 & 6.1 & 2.66 \\
\hline & Focal + diffuse findings & 5 & 6.1 & 2.66 \\
\hline & Scattered abnormalities, no focus formation & 3 & 3.7 & - \\
\hline
\end{tabular}




\subsection{Efficacy of Oxcarbazepine treatment}

We did not find a significant difference in the percentage of patients without improvement of seizure severity up to the $24^{\text {th }}$ month of treatment. The percentage of participants with seizure severity reduction increased slightly between the $6^{\text {th }}$ and $24^{\text {th }}$ month $\left(9.8 \%\right.$ on the $6^{\text {th }}$ month, $10.9 \%$ on the $12^{\text {th }}$ month, $11.6 \%$ on the $24^{\text {th }}$ month). Because of the small number of patients, who continued OCBZ treatment after the $24^{\text {th }}$ month, they were not included in statistical analysis. We came to the conclusion about a mild and stable improvement of seizure severity by treatment with OCBZ. There was no correlation of seizure severity dynamics with the initial seizure severity on the $6^{\text {th }}, 12^{\text {th }}$ and $24^{\text {th }}$ month of treatment $\mathrm{P}>0.05\left(\chi^{2}=1.19 ; \chi^{2}=1.10 ; \chi^{2}=1.00\right.$ respectively $)$, with the dosage of OCBZ $\mathrm{P}>0.05\left(\chi^{2}=\right.$ 10.62), and any demographic or other clinical findings.

The assessment of seizure frequency up to the $24^{\text {th }}$ month of OCBZ treatment is presented in Table 2.

Table 2 Seizure frequency assessment during treatment with OCBZ

\begin{tabular}{llllll}
\hline & \multicolumn{3}{l}{ Seizure frequency dynamics } & Total \\
\cline { 2 - 5 } & No change & Reduction $\mathbf{5 0 - 9 9 \%}$ & Reduction 100\% & Increase & $\mathrm{N}(\mathrm{p} \%)$ \\
& $\mathrm{N}(\mathrm{p} \%)$ & $\mathrm{N}(\mathrm{p} \%)$ & $\mathrm{N}(\mathrm{p} \%)$ & $\mathrm{N}(\mathrm{p} \%)$ & \\
$6^{\text {th }}$ month & $46(56.1 \%)$ & $30(36.6 \%)$ & $2(2.4 \%)$ & $4(4.9 \%)$ & $82(100.0 \%)$ \\
$12^{\text {th }}$ month & $31(48.4 \%)$ & $22(34.4 \%)$ & $2(3.1 \%)$ & $9(14.1 \%)$ & $64(100.0 \%)$ \\
$24^{\text {th }}$ month & $16(43.2 \%)$ & $16(43.2 \%)$ & $2(5.4 \%)$ & $3(8.2 \%)$ & $37(100.0 \%)$ \\
\hline
\end{tabular}

The most significant improvement of seizure frequency was on the $6^{\text {th }}$ month of treatment followed by retention of a high responder rate of about $40 \%$ (39\% on the $6^{\text {th }}$ month, $37.5 \%$ on the $12^{\text {th }}$ month, $48.6 \%$ on the $24^{\text {th }}$ month) and slight increase of the percentage of patients without seizures - Table 2. The tendency of seizure frequency dynamic changes during the 36 months of treatment is shown in Fig. 1. The statistical analysis of results confirmed that there was no significant decrease in seizure frequency between the $6^{\text {th }}$ and $24^{\text {th }}$ month $P>0.05\left(\chi^{2}=6.23\right)$. We found the following dynamics in the mean seizure frequency reduction with no statistically significant differences -40.21 on the $6^{\text {th }}$ month, $41.12 \%$ on the $12^{\text {th }}$ month, $38.55 \%$ on the $24^{\text {th }}$ month $\mathrm{P}>0.05$ (Friedman Test $=0.5$ ). Therefore, regarding seizure frequency, the efficacy of OCBZ was good and stable for the study period. There was no correlation of seizure frequency dynamics with the initial seizure frequency on the $6^{\text {th }}, 12^{\text {th }}$ and $24^{\text {th }}$ month of treatment $P>0.05\left(\chi^{2}=18.36\right.$; $\chi^{2}=14.89 ; \chi^{2}=12.80$ respectively), with the dosage of OCBZ P $>0.05\left(\chi^{2}=17.34\right)$, and any demographic or other clinical findings.

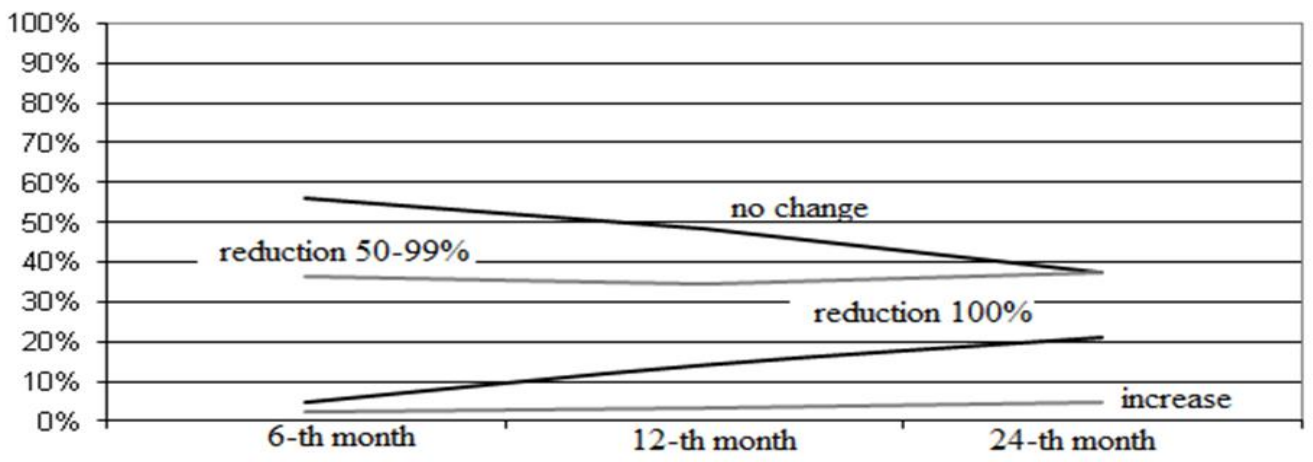

Figure 1 Dynamic assessment of seizure frequency in patients treated with OCBZ

Seizure frequency improvement by various combinations of OCBZ with other AEDs at the end of the study is presented in Table 3. 
Table 3 Seizure frequency improvement by various combinations of OCBZ with other AEDs at the end of the study

\begin{tabular}{|c|c|c|c|c|c|}
\hline \multirow{3}{*}{$\begin{array}{l}\text { AEDs in combination with } \\
\text { OCBZ ( } \mathrm{mg} / \mathrm{d})\end{array}$} & \multicolumn{4}{|c|}{ Seizure frequency change at the end of the study } & \multirow{2}{*}{$\begin{array}{l}\text { Total } \\
\text { N (p\%) }\end{array}$} \\
\hline & $0-50 \%$ & $50-75 \%$ & $75-99 \%$ & Increase & \\
\hline & $\mathrm{N}(\mathrm{p} \%)$ & $\mathrm{N}(\mathrm{p} \%)$ & $\mathrm{N}(\mathrm{p} \%)$ & $\mathrm{N}(\mathrm{p} \%)$ & \\
\hline $\begin{array}{l}\text { - Monotherapy OCBZ 1200-1500 } \\
\mathrm{mg} / \mathrm{d}\end{array}$ & $4(50 \%)$ & $4(50 \%)$ & $0(0 \%)$ & $0(0 \%)$ & $8(100 \%)$ \\
\hline - VPA $900-2000 \mathrm{mg} / \mathrm{d}$ & $24(60 \%)$ & $5(12.5 \%)$ & $2(5 \%)$ & $9(22.5 \%)$ & $40(100 \%)$ \\
\hline - CZP 2-6 mg/d & $0(0 \%)$ & $0(0 \%)$ & $1(50 \%)$ & $1(50 \%)$ & $2(100 \%)$ \\
\hline - TPM $300-400 \mathrm{mg} / \mathrm{d}$ & $2(66.7 \%)$ & $0(0 \%)$ & $0(0 \%)$ & $1(33.3 \%)$ & $3(100 \%)$ \\
\hline - PHT 150 mg/d & $1(100 \%)$ & $0(0 \%)$ & $0(0 \%)$ & $0(0 \%)$ & $1(100 \%)$ \\
\hline - LTG $250 \mathrm{mg} / \mathrm{d}$ & $0(0 \%)$ & $1(100 \%)$ & $0(0 \%)$ & $0(0 \%)$ & $1(100 \%)$ \\
\hline $\begin{array}{l}\text { - VPA } 1500-1750 \mathrm{mg} / \mathrm{d}+\text { LEV } \\
2000 \mathrm{mg} / \mathrm{d}\end{array}$ & $0(0 \%)$ & $1(100 \%)$ & $0(0 \%)$ & $1(50 \%)$ & $2(100 \%)$ \\
\hline $\begin{array}{l}\text { - VPA 600-2000 mg/d + LTG 200- } \\
300 \mathrm{mg} / \mathrm{d}\end{array}$ & $0(0 \%)$ & $2(50 \%)$ & $1(50 \%)$ & $1(50 \%)$ & $4(100 \%)$ \\
\hline $\begin{array}{l}\text { - VPA } 1500-2000 \mathrm{mg} / \mathrm{d}+\mathrm{TPM} \\
100-200 \mathrm{mg} / \mathrm{d}\end{array}$ & $3(60 \%)$ & $0(0 \%)$ & $2(40 \%)$ & $0(0 \%)$ & $5(100 \%)$ \\
\hline $\begin{array}{l}\text { - VPA } 1500-2500 \mathrm{mg} / \mathrm{d}+\mathrm{CZP} \\
1.5-6 \mathrm{mg} / \mathrm{d}\end{array}$ & $2(40 \%)$ & $1(20 \%)$ & $1(20 \%)$ & $1(20 \%)$ & $5(100 \%)$ \\
\hline $\begin{array}{l}- \text { VPA } 1250-1750 \mathrm{mg} / \mathrm{d}+\mathrm{GBP} \\
1200-1600 \mathrm{mg} / \mathrm{d}\end{array}$ & $2(50 \%)$ & $1(25 \%)$ & $0(0 \%)$ & $1(25 \%)$ & $4(100 \%)$ \\
\hline - CZP $2 \mathrm{mg} / \mathrm{d}+\mathrm{LTG} 300 \mathrm{mg} / \mathrm{d}$ & $1(100 \%)$ & $0(0 \%)$ & $0(0 \%)$ & $0(0 \%)$ & $1(100 \%)$ \\
\hline - PHT 200 mg/d + LTG 300 mg/d & $1(100 \%)$ & $0(0 \%)$ & $0(0 \%)$ & $0(0 \%)$ & $1(100 \%)$ \\
\hline$-\mathrm{TGB} 40 \mathrm{mg} / \mathrm{d}+\mathrm{CZP} 2 \mathrm{mg} / \mathrm{d}$ & $0(0 \%)$ & $0(0 \%)$ & $0(0 \%)$ & $1(100 \%)$ & $1(100 \%)$ \\
\hline - LEV 2000 mg/d + CZP 6 mg/d & $1(100 \%)$ & $0(0 \%)$ & $0(0 \%)$ & $0(0 \%)$ & $1(100 \%)$ \\
\hline - LTG $250 \mathrm{mg} / \mathrm{d}+\mathrm{PGB} 300 \mathrm{mg} / \mathrm{d}$ & $1(100 \%)$ & $0(0 \%)$ & $0(0 \%)$ & $0(0 \%)$ & $1(100 \%)$ \\
\hline $\begin{array}{l}- \text { VGB } 1000 \mathrm{mg} / \mathrm{d}+\text { LTG } 300 \\
\mathrm{mg} / \mathrm{d}+\mathrm{LEV} 2000 \mathrm{mg} / \mathrm{d}\end{array}$ & $0(0 \%)$ & $0(0 \%)$ & $1(100 \%)$ & $0(0 \%)$ & $1(100 \%)$ \\
\hline $\begin{array}{l}- \text { VPA } 1500 \mathrm{mg} / \mathrm{d}+\text { TPM } 200 \\
\mathrm{mg} / \mathrm{d}+\text { CZP } 3 \mathrm{mg} / \mathrm{d}\end{array}$ & $0(0 \%)$ & $1(100 \%)$ & $0(0 \%)$ & $0(0 \%)$ & $1(100 \%)$ \\
\hline
\end{tabular}

The small number of patients treated with various combinations is a limitation for statistical analyses. No patient was seizure free. The combination with VPA proved to be more frequent - in $40(78.78 \%)$ participants. It was effective in only $7(17.5 \%)$ patients. OCBZ was used as monotherapy in $8(9.76 \%)$ participants, $4(50 \%)$ were responders.

At the end of the study seizure frequency was increased in 18 (22\%) participants, there was no or unsatisfactory improvement (seizure frequency reduction $<50 \%)$ in $43(52.4 \%)$ patients. Responders were 21 (25.6\%) patients - 15 $(18.3 \%)$ were with seizure reduction $50-75 \%, 6(7.3 \%)$ - with seizure reduction $>75 \%$, without seizure free patients. The final seizure frequency reduction did not correlate with any clinical or demographic findings $\mathrm{P}>0.05$.

There was no modification of seizure type in any of the study participants.

In 11 (13.4\%) study participants OCBZ treatment was terminated for various reasons: 1 . Adverse events from treatment - in $5(6.1 \%)$ patients; 2. Lack of efficacy, transient efficacy or increased seizure frequency - in 6 (7.3\%) patients.

In 5 patients OCBZ was stopped very early (before the $6^{\text {th }}$ month of treatment, on the $12^{\text {th }}$ month - in 3 patients, on the $24^{\text {th }}$ month - in 3 patients. Therefore, we found a gradual and mild decrease of the percentage of patients continuing OCBZ treatment, i.e. the retention rate was $96.34 \%$ on the $6^{\text {th }}$ month, $90.24 \%$ on the $12^{\text {th }}$ month, and $86.59 \%$ on the $24^{\text {th }}$ month. The total duration of OCBZ treatment was 1962 months. The total duration of effectiveness was 722 
months, therefore OCBZ was effective in $36.8 \%$ of the treatment time of all patients. The mean effectiveness duration was $8.8 \pm 0.44$ months. The effectiveness duration is presented in Table 4 .

Table 4 Duration of OCBZ effectiveness

\begin{tabular}{llll}
\hline Effectiveness & Number of patients (N) & P\% & SE \\
\hline Worsening & 4 & 4.9 & - \\
No effect & 45 & 54.9 & 5.53 \\
6 months & 10 & 12.3 & 3.65 \\
12 months & 5 & 6.1 & 2.66 \\
18 months & 2 & 2.4 & - \\
22 months & 1 & 1.2 & - \\
24 months & 7 & 8.5 & 3.10 \\
30 months & 1 & 1.2 & - \\
34 months & 1 & 1.2 & - \\
36 months & 3 & 3.7 & - \\
48 months & 1 & 1.2 & - \\
60 months & 1 & 1.2 & - \\
96 months & 1 & 1.2 & - \\
Total & 82 & 100.0 & \\
\hline
\end{tabular}

\subsection{Safety and tolerability of OCBZ treatment}

There were adverse events from treatment in 7 (8.54\%) of study participants, without any correlation with OCBZ dosage $\mathrm{P}>0.05\left(\chi^{2}=8.63\right)$. The distribution of patients with somatic and associated with the central nervous system (CNS) adverse events according to OCBZ dosage is presented in Table 5.

Table 5 Distribution of patients with somatic and associated with the CNS adverse events according to OCBZ dosage

\begin{tabular}{|c|c|c|c|c|c|c|c|c|c|c|}
\hline \multicolumn{3}{|c|}{ Adverse events } & \multicolumn{7}{|c|}{ OCBZ dosage $(\mathrm{mg} / \mathrm{d})$} & \multirow[t]{2}{*}{ Total } \\
\hline & & & 600 & 750 & 900 & 1200 & 1500 & 1800 & 2100 & \\
\hline \multirow[t]{2}{*}{ No } & $\mathrm{N}$ & 6 & 1 & 10 & 37 & 5 & 15 & 1 & 1 & 75 \\
\hline & $\mathrm{P} \%$ & $85.7 \%$ & $100.0 \%$ & $90.9 \%$ & $90.2 \%$ & $100.0 \%$ & $93.8 \%$ & $100.0 \%$ & $100.0 \%$ & $100.0 \%$ \\
\hline \multirow[t]{2}{*}{ Somatic } & $\mathrm{N}$ & 0 & 0 & 1 & 4 & 0 & 0 & 0 & 0 & 5 \\
\hline & $\mathrm{P} \%$ & $0 \%$ & $0 \%$ & $9.1 \%$ & $9.8 \%$ & $0 \%$ & $0 \%$ & $0 \%$ & $0 \%$ & $100.0 \%$ \\
\hline \multirow{2}{*}{$\begin{array}{l}\text { Associated } \\
\text { with CNS }\end{array}$} & $\mathrm{N}$ & 1 & 0 & 0 & 0 & 0 & 1 & 0 & 0 & 2 \\
\hline & $\mathrm{P} \%$ & 4.3 & $0 \%$ & $0 \%$ & $0 \%$ & $0 \%$ & $6.2 \%$ & $0 \%$ & $0 \%$ & $100.0 \%$ \\
\hline \multirow{2}{*}{$\begin{array}{l}\text { Somatic + } \\
\text { associated } \\
\text { with CNS }\end{array}$} & $\mathrm{N}$ & 0 & 0 & 0 & 0 & 0 & 0 & 0 & 0 & 0 \\
\hline & $\mathrm{P} \%$ & $0 \%$ & $0 \%$ & $0 \%$ & $0 \%$ & $0 \%$ & $0 \%$ & $0 \%$ & $0 \%$ & $0 \%$ \\
\hline \multirow[t]{2}{*}{ Total } & $\mathrm{N}$ & 7 & 1 & 11 & 41 & 5 & 16 & 1 & 1 & 82 \\
\hline & $\mathrm{P} \%$ & $8.54 \%$ & $1.22 \%$ & $13.41 \%$ & $50.0 \%$ & $6.10 \%$ & $19.51 \%$ & $1.22 \%$ & $1.22 \%$ & $100.0 \%$ \\
\hline
\end{tabular}

More detailed information about adverse events is included in Table 6 
Viteva and Zahariev / World Journal of Advanced Research and Reviews, 2019, 03(03), 001-010

Table 6 Adverse events from OCBZ treatment

\begin{tabular}{llllll}
\hline Adverse event & $\begin{array}{l}\text { Number } \\
\text { of } \\
\text { patients }\end{array}$ & $\begin{array}{l}\text { Dosage } \\
\mathbf{( m g / d )}\end{array}$ & Severity & OCBZ termination & Duration \\
\hline Generalized rash & 1 & 1200 & Severe & Yes & 180 days \\
& 1 & 1200 & Severe & Yes & 80 days \\
Memory problems & 1 & 1200 & Severe & Yes & 30 days \\
Edemas of & 1 & 600 & Moderate & No & 10 days \\
extremities & 1 & 1200 & Severe & Yes & 180 days \\
Dizziness & 1 & 1800 & Moderate & No, decreased dose & 14 days \\
Nausea, vomiting & 1 & 900 & Moderate & Yes & 180 \\
\hline
\end{tabular}

The generalized rash was a more frequent and typical adverse event which was associated with drug termination in all patients. Edemas of the extremities were another severe adverse event. The other adverse events were of moderate severity and did not necessitate drug termination. We did not confirm a correlation of adverse events with demographic and clinical factors.

\section{Discussion}

In our study OCBZ was applied as add-on treatment in 82 patients of mean age 40 years with long duration epilepsy with predominant severe and very frequent focal with or without evolution to bilateral tonic-clonic seizures, a combination of focal and generalized, and generalized tonic-clonic seizures, refractory to the prescribed, usually combined treatment with a variety of AEDs.

There was mild and stable dynamic improvement of seizure severity. These results could not be compared with other studies, for the lack of literature data.

The described above satisfactory seizure frequency reduction in $25.6 \%$ of participants (no seizure free), the stable mean seizure frequency reduction (40.21-38.55\%) from the $6^{\text {th }}$ to the $24^{\text {th }}$ month of the study, as well as the high and stable responder rate (39-41.9\%) during the same period, differ from the presented in literature results from doubleblind, randomized studies $(359,381)$, and to those from some open prospective studies [6, 8-11] with: a relatively lower responder rate, the lack of significant dynamics in efficacy in the study course, and the lack of dose-dependent effect. Investigators have not focused attention on the percentage of patients with worsened seizure control during OCBZ treatment, probably because of the uncertain association with drug intake in all patients. The percentage of our study participants with worse seizure control, without improvement or minimal efficacy, is not a small one $(22 \%$ and $52.4 \%$ respectively), and suggests focusing attention in future studies, moreover the lack of efficacy is the reason for OCBZ treatment termination in $7.3 \%$ of study participants. The combination of OCBZ with VPA was more frequent (48.78\%), although rarely effective $-17.5 \%$ were responders. Of the participants on monotherapy with 0 CBZ $50 \%$ were responders which corresponds to literature data from similar prospective studies [12, 13]. Most treatment changes during the first 12 months of study were mainly of the concomitant AEDs, probably associated with the necessity of treatment adaptation following the initial clinical improvement and the manifestation of adverse events. This finding also explains the slight decrease of the percentage of patients continuing OCBZ treatment from $96.34 \%$ on the $6^{\text {th }}$ month to $86.59 \%$ on the $24^{\text {th }}$ month. We did not find studies in literature focusing attention on retention rate of OCBZ.

OCBZ showed very good safety and tolerability in our study participants. The frequency of reported adverse events $(8.54 \%)$ was lower than literature data, they were usually with moderate and severe and became a cause of treatment termination in a small, and similar to other studies percentage of patients $-6.1 \%[1,10,12-19]$. Moderate memory impairment as an unusual adverse event was found in 1 patient, but it continued for a long period of time and did not result in OCBZ termination. The reported by 1 patient dizziness was associated with a dose reduction of OCBZ, while the observed nausea and vomiting in another patient resulted in OCBZ termination. The most severe adverse events associated with termination of OCBZ treatment were: generalized rash (3 patients), and edemas in the extremities (1 
patient). Most adverse events were similar to the ones reported in literature and were not associated with a higher OCBZ dose $[1,16,17,19-21]$.

\section{Conclusion}

OCBZ treatment is characterized with: a low and stable improvement of seizure severity, a good and stable reduction of seizure frequency, a possibility of worsening of seizure control, a very good safety and tolerability. Future studies are needed with emphasis on seizure control worsening by OCBZ treatment and correlations of efficacy and adverse events from treatment with patients' demographic and clinical characteristics.

\section{Compliance with ethical standards}

\section{Acknowledgments}

There are no acknowledgements to mention.

\section{Disclosure of conflict of interest}

We have no conflict of interest to disclose.

\section{Statement of ethical approval}

All study procedures were performed after the approval of the Local Ethics Commission at the Medical University, Plovdiv.

\section{Statement of informed consent}

Informed consent was obtained from all individual participants included in the study.

\section{References}

[1] Barcs G, Walker EB, Elger CE, Scaramelli A, Stefan H, Sturm Y, Moore A, Flesch G, Kramer L and D'Souza J. (2000). Oxcarbazepine placebo-controlled, dose-ranging trial in refractory partial epilepsy. Epilepsia, 41(12), 1597-1607.

[2] Schachter SC, Vazquez B, Fisher RS, Laxer KD, Montouris GD, Combs-Cantrell DT, Faught E, Willmore LJ, Morris GL, Ojemann L, Bennett D, Mesenbrink P, D'Souza J and Kramer L. (1999). Oxcarbazepine: double-blind, randomized, placebo-control, monotherapy trial for partial seizures. Neurology, 52(4), 732-737.

[3] Beydoun A, Sachdeo RC, Rosenfeld WE, Krauss GL, Sessler N, Mesenbrink P, Kramer L and D'Souza J. (2000). Oxcarbazepine monotherapy for partial-onset seizures: a multicenter, double-blind, clinical trial. Neurology, 54(12), 2245-2251.

[4] Sachdeo R, Beydoun A, Schachter S, Vazquez B, Schaul N, Mesenbrink P, Kramer L and D'Souza J. (2001). Oxcarbazepine (Trileptal) as monotherapy in patients with partial seizures. Neurology, 57(5), 864-871.

[5] Kang HC, Hu Q, Liu XY, Liu ZG, Zeng Z, Liu JL, Wang M, Liang YL and Zhu SQ. (2012). A follow-up study on newer anti-epileptic drugs as add-on and monotherapy for partial epilepsy in China. Chin Med J (Engl), 125(4), 646651.

[6] Houtkooper MA, Lammertsma A, Meyer JWA, Goedhart DM and van Oorschot CM. (1987). Oxcarbazepine (GP 47.680): a possible alternative to carbamazepine. Epilepsia, 28, 693-698.

[7] Kuzmanova R. (2015). Adverse events from treatment with antiepileptic drugs - importance for the therapeutic approach and impact on the quality of life of patients with epilepsy. Ph.D. thesis, Medical University - Sofia.

[8] Rasheva M, Milanova M, Radeva M and Atanassova D. (2004). Assessment of the newer antiepileptic drugs as add-on therapy in resistant partial epilepsies. Bulgarian Neurology, 4(4), 173-178.

[9] Burd SG, Glukhova LIu and Badalian OL. (2010). Efficacy and safety of the mono- and combined therapy with oxcarbazepine in adult patients. Zh Nevrol Psikhiatr Im S S Korsakova, 110(6), 66-69.

[10] Freidel M, Krause E, Kuhn K, Peper R and Vogel H. (2007). Oxcarbazepine in the treatment of epilepsy. See comment in PubMed Commons belowFortschr Neurol Psychiatr, 75(2), 100-106. 
[11] Kraiprab P, Chinvarun Y and Tantisira MH. (2005). Oxcarbazepine as add-on therapy in Thai epileptic patients with refractory partial seizures. J Med Assoc Thai, 88 Suppl 3, S193-201.

[12] Martinez W, Ingenito A, Blakeslee M, Barkley GL, McCague K and D'Souza J. (2006). Efficacy, safety, and tolerability of oxcarbazepine monotherapy. Epilepsy Behav, 9(3), 448-456.

[13] Friis ML, Kristensen O, Boas J, Dalby M, Deth SH, Gram L, Mikkelsen M, Pedersen B, Sabers A, Worm-Petersen J, Andersen D and Jensen PK. (1993). Therapeutic experiences with 947 epileptic out-patients in oxcarbazepine treatment. Acta Neurol Scand, 87, 224-227.

[14] Shaju M and Abraham S. (2013) Innovations in epilepsy management - an overview. J Pharm Pharm Sci, 16(4), 564-676.

[15] Marson AG, Al-Kharusi AM, Alwaidh M, Appleton R, Baker GA, Chadwick DW, Cramp C, Cockerell OC, Cooper PN, Doughty J, Eaton B, Gamble C, Goulding PJ, Howell SJ, Hughes A, Jackson M, Jacoby A, Kellett M, Lawson GR, Leach JP, Nicolaides P, Roberts R, Shackley P, Shen J, Smith DF, Smith PE, Smith CT, Vanoli A, Williamson PR and SANAD Study group. (2007). The SANAD study of effectiveness of carbamazepine, gabapentin, lamotrigine, oxcarbazepine, or topiramate for treatment of partial epilepsy: an unblinded randomised controlled trial. Lancet, 369(9566), 1000-1015.

[16] Bill PA, Vigonius U, Pohlmann H, Guerreiro CA, Kochen S, Saffer D and Moore A. (1997). A doubleblind controlled clinical trial of oxcarbazepine versus phenytoin in adults with previously untreated epilepsy. Epilepsy Res, 27, 195-204.

[17] Christe W, Kramer G, Vigonius U, Pohlmann H, Steinhoff BJ, Brodie M and Moore A. (1997). A double-blind controlled clinical trial: oxcarbazepine versus sodium valproate in adults with newly diagnosed epilepsy. Epilepsy Res, 26, 451-460.

[18] Dam M, Ekberg R, Loyning Y, Waltimo O and Jakobsen K. (1989). A double-blind study comparing oxcarbazepine and carbamazepine in patients with newly diagnosed, previously untreated epilepsy. Epilepsy Res, 3, 70-76.

[19] Beydoun A, Sachdeo RC, Kutluay E, McCague K and D'Souza J. (2003). Sustained efficacy and long-term safety of oxcarbazepine: one-year open-label extension of a study in refractory partial epilepsy. Epilepsia, 44(9), 11601165.

[20] Guerreiro CAM and Guerreirol MM. (2011). Carbamazepine and oxcarbazepine. In: Wyllie E. (ed.). Wyllie's Treatment of Epilepsy, Principles and Practice, 5th edn, Lippincott Williams and Wilkins: Philadelphia PA, 614621.

[21] Guerreiro MM, Vigonius U, Pohlmann H, de Manreza ML, Fejerman N, Antoniuk SA and Moore A. (1997). A double-blind controlled clinical trial of oxcarbazepine versus phenytoin in children and adolescents with epilepsy. Epilepsy Res, 27, 205-213.

\section{How to cite this article}

Viteva EI and Zahariev ZI. (2019). Oxcarbazepine effectiveness as add-on therapy in Bulgarian patients with drugresistant epilepsy. World Journal of Advanced Research and Reviews, 3(3), 01-10. 